\title{
全方向ステレオカメラ(SOS)を用いた電動車いすアクティブ・セーフティシステムの検討 Examination of a Wheelchair Active Safety System using a Stereo Omni-directional Camera System
}

\author{
○佐藤雄隆，坂上勝彦 \\ 産業技術総合研究所 情報技術研究部門 \\ OYutaka Satoh and Katsuhiko Sakaue \\ Information Technology Research Institute, AIST
}

\section{1. はじめに}

近年電動車いすの普及により，従来は外出が困難であった高 齢者や障害者でも，自由に外出できるようになりつつある.しかし 一方で, 衝突や転倒, 移動中の突然の体調不良などの事故が増 加しておりり，走行中に起きるさまざまな危険を険出して安全な走 行を確保する機能と, ユーザの意図や異常を機械がキャッチして 「ユーザを見守る」ための機能の実現が望まれている.

近年自動車では，追突の危険性を事前に予測して自動的にフ レーキをかけたり，自動的に前走車に追従するなどのインテリジェ ントシステムが既に実用化されている. しかし，道路を走行する自 動車と異なり電動車いすは, 家具の置かれた室内や人混みなど さまざまな生活空間での使用が前提となるため, その実現には次 世代のセンシング技術を用いる必要があった。

そこで本研究では，前後・上下・左右すべて死角のない全方向 のカラー動画像と3次元情報を，同時にリアルタイムで取得する 能力を持つ「全方向ステレオシステム(Stereo Omni-directional System：以下SOS と表記) 1」を電動車いすに搭载し，障害物一 の䘖突や段差からの落下などの危険を未然に防止する機能や, ユーザの乗車姿勢やジェスチャなどを認識する機能など,安心で 安全な移動を支援するための様々な機能を持つインテリジェント 電動車いすを開発した.

\section{2. システムの砳要}

SOS (Fig. 1 右)は, 直径 $11.6 \mathrm{~cm}$, 重さ $615 \mathrm{~g}$ という, 極めてコン パクトな形状でありながら, 全く死角無く全天周のカラー画像と距 離情報を高解像度かつリアルタイムに取得することができるカメラ システムである. Fig. 1 左に示すように SOS はユーザの頭上に設 居される.このときの走行面からの高さは約 $150 \mathrm{~cm}$ である. 人間の 步行時における目の高さに相当するこの位置は, 生活環境中の 危険を検出するうえで合理的である. また，(1)人間の身長と同 等かやや低い位置であるため, 人間が通常歩行で通過できる場 所であれば,カメラが障害物に干渉しない，(2)電動車いすの周 囲を良好に見わたすことができる，(3) 周囲の環境とユーザの状 態を同時に観測可能である, などの特長がある.

座席後部には画像情報の処理および車いすのコントロールを おこなう統合制御 PC が車載されている.電源は電動車いすの走 行用バッテリを共用するため, 外部ケーブルなどを一切必要とせ ず, 単独で約 4 時間の走行が可能である.

\section{3. 英駼}

SOSでは, 約 20 万点にもおよぶ全方向距離情報を, 1 秒間に 15 回取得することができるので, これを用いて走行環境における 危険因子の検出を行うことができる. ジョイスティックを倒している 方向を考虑した検出エリアを設け，検出エリア内で電動車いすか ら近い位圈に危険因子が検出された場合，ユーザのジョイスティ ック入力に関わらず，自動的に減速・停止の制御を行う. Fig. 2 に危険検出の例を示す. 壁などの障害物だけでなく, 床より低い 段差の検出も同時に行っているため, 図のような場合でも自動的 に停止することができる. 図中左下に示した表示は，電動車いす に設置した状態表示用の PDA に表示される画面で, 障害が検 出された方向と, 障害の種類, および制御介入の状況がアイコン 表示により一目で確認できるようになっている.

Fig. 3 はユーザのジェスチャを怨識し, 制御を行っている例で

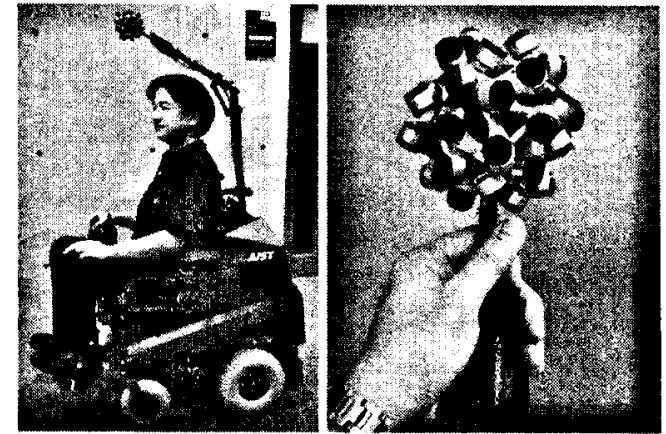

Fig. 1 インテリジェント電動車いすと全方向ステレオシステム

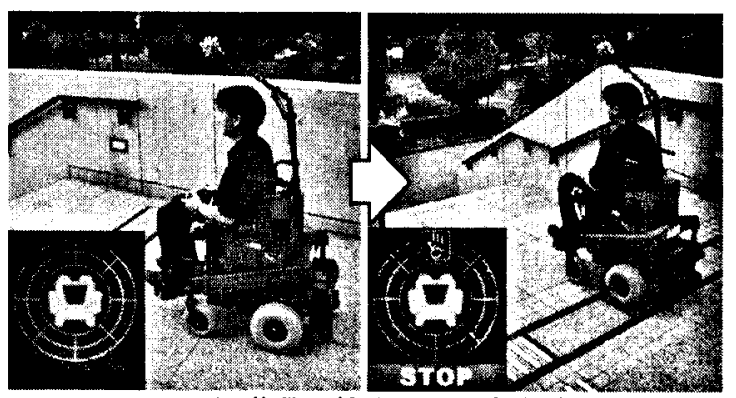

Fig.2 下り階段の検出および自動停止

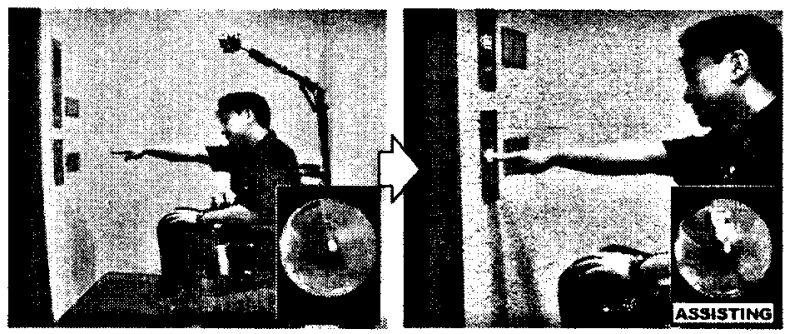

Fig. 3 ユーザのジェスチャによるコントロール

ある. SOS はューザの頭上に設置されているため, 周囲環境だ けでなくユーザの状態も良好に観測することができる.ここでは， ユーザが一定時間手を伸ばしていると, 微速前進を開始し, 手を 戻すか, 障害物と干涉する直前で自動的に停止する. ジョイステ イックによる操作は熟練を要するため, 障害物に近つくく動作を行う 場合には危険が伴うが、これによって図のような例でも安全にア プローチすることができる.

\section{4. まとぬ}

電動車いすの安全を積極的に確保するためのシステムの開発 について述べた. 今後は,レーザーレンジファインダなど異種の センサとのハイブリッド化による精度向上などを検討する予定であ る.

\section{5. 孝文林}

（1）佐藤, 山本, 桑島, 棚楿, 王, 丹羽, “移動体ビジョンを指向 した小型全方向ステレオシステム(miniSOS)の開発”, 第 9 回画 像センシシグシンポジウム(SSII03)論文集, pp.311-316, 2003. 